\title{
Student performance in online and face-to-face second language courses: Dutch L2 in adult education
}

Liesbeth DE PAEPE•

\begin{abstract}
Due to immigration, globalization and a changing labor market, there is a recognized need for flexible learning. In Europe, second language (L2) acquisition specifically has become of vital importance. Research on less commonly taught languages (LCTL), however, is scarce and focuses mainly on foreign language acquisition, compulsory education and on face-toface (F2F) and blended learning. However, the effectiveness of learning a LCTL - such as Dutch - as a second language fully online in adult education has yet to be uncovered. The principal objective of this paper was to investigate whether learning Dutch L2 fully online can be as effective as learning it fully F2F. A quantitative methodological approach was adopted. Independent samples t-tests were carried out to compare online and F2F adult learners' performance in a Waystage-level Dutch L2 course in Flanders, Belgium. The key variables 'previous knowledge', 'course level', 'content', 'teacher', 'assessment' and 'learning outcomes' are controlled. Main findings indicated that online Dutch L2 learning in adult education can be at least as effective as F2F learning. This study should, therefore, be of value to language course providers wishing to implement flexible L2 learning, and to LCTL and computerassisted language learning (CALL) researchers.
\end{abstract}

Keywords: second language learning (L2 learning); online learning; adult education; effectiveness; computer-assisted language learning (CALL)

\footnotetext{
•Ph.D. candidate, Vrije Universiteit Brussel, Brussels, Belgium, liesbeth.depaepe@gmail.com
} 


\section{Introduction}

The past decade has seen the rapid development of innovative ways of L2 learning and teaching for many languages, including the less commonly taught languages (LCTLs). Despite the increased interest in blended L2 learning and teaching and the growing number of initiatives to set up blended language courses, there is a dearth of studies on fully online language courses (Blake and Delforge, 2007; Sun, 2014), especially of studies comparing the learning results of fully online and face-to-face learners (Blake, 2013; Coleman and Furnborough, 2010).

Providing fully online courses for a LCTL is hardly comparable to providing a commonly taught language course online, because there are fewer readily-available learning resources, and because institutions have smaller scales and correspondingly lower budgets and fewer skilled teachers to develop online courses and to teach online. Moreover, the target groups for LCTL courses are smaller, and at the same time, learners have very diverse learning needs: some take Dutch L2 courses for professional reasons (and the professions and corresponding learning needs also vary greatly), others because they want to enter university; because they want to get by in everyday life or because they have children in a Flemish-speaking school and wish to communicate with the teachers. Along with the fact that setting up online learning for a LCTL is challenging, there is also a reluctance or even disbelief in the efficacy of learning a language online, especially when it comes to the oral skills. Blake (2013)remarks that those who question the efficacy of distance learning for languages, are especially concerned with oral proficiency, and "finding the answer is particularly important in the case of the less commonly taught languages (LCTLs), where access to beginning instruction is especially limited due to teacher shortages, low enrollments, and the concomitant financial constraints." (p130-131).

At the time the current research is carried out, there is one center for adult education offering fully online Dutch L2 courses. As White (2016) states, there are two main reasons for assessing online language learners' acquisition of the target language skills: "to investigate student gains in performance as a means of establishing the effectiveness of distance language teaching environments and processes (Volle, 1995; Blake et al., 2008) and/or as a means of assessing particular skills and providing feedback to learners on their 
progress" (p142). This study relates to the first reason: to find out whether online Dutch L2 learning can provide an alternative for F2F Dutch L2 learning, for those students who are in need of a different learning format.

While some comparative studies have been carried out to determine learning results in blended learning or online and F2F foreign language learning, there is a notable paucity of well-controlled studies in the field of second language acquisition specifically comparing learning results in fully online and fully F2F courses. Even fewer studies have addressed a LCTL, like Dutch.Most studies suffer from a weak methodology (comparing different proficiency levels, using different assessment tasks, including different teachers...). "The burden of isolating the experimental treatment so as to focus on the medium alone (DL vs. classroom instruction), to the exclusion of all other factors, remains a daunting, if not insurmountable, challenge. (...) One of the difficulties in this line of research is isolating the format variable from all the other factors that contribute to L2 learning outcomes - for example, learner characteristics, instructional method, and media attributes." (Blake, 2013, p144).

The current study provides a quantitative analysis of student performance in fully online and fully F2F Dutch L2 courses. It accommodates these challenges by controlling the key variables 'previous knowledge', 'course level', 'content', 'teacher', 'assessment' and 'learning outcomes'.The study is set in formal adult education in Flanders, Belgium. By the time the research is carried out, there is an increasing interest in blended learning. Several centres for adult education (Centra voor Volwassenenonderwijs (CVO), providing general language courses) have set out to organize blended learning Dutch L2 courses in addition to the mainstream, face-to-face curriculum. The proportion of distance learning in these courses may vary greatly, in extreme cases it can be $5 \%$ up to $95 \%$. As $95 \%$ distance learning is legally the maximum allowed part of distance learning, and is considered fully online learning. Most schools offering blended learning, opt for less than 50\% distance learning. The Dutch L2 courses which are subject of this study, are organized online for 95\%. Learners only come to school once, to take the final exam.

The main aim of this study is to investigate the differences in learning outcomes between fully online and F2F learners of Dutch L2 and thus to find out if fully online Dutch L2 learning can be as effective as F2F learning. The specific questions which drive the 
research are:

- RQ1: Are the learning achievements significantly different in online and F2F learning modes?

\section{Literature review}

The importance and originality of this study is that it compares the performance of fully online and fully F2F students of a less commonly taught language, Dutch, for which no previous research is available.In Brave New Digital Classroom, Blake (2013) reports on several online language evaluation studies. He concludes that "the result of no significant difference between the in-class students and the online students was the most frequent finding from these comparative studies for first-year language study. Occasionally, the online students performed slightly better, but never worse." (p146).

When looking at reading, writing and listening skills, Chenoweth, Jones and Tucker (2006) and Chenoweth and Murday (2003) found minimal statistical differences in learning results in Spanish and French courses respectively. There is only a small body of literature that is concerned with the assessment of oral proficiency in online L2 courses (Moneypenny \& Aldrich, 2016). Though oral skills are claimed to be difficult to handle in online learning formats (Sánchez-Serrano, 2008), existing studies showed no significant differences between the oral skills of online and F2F learners (Blake, R., Wilson, N., Pardo Ballester, C. and Cetto, 2008; Chenoweth, Jones and Tucker, 2006; Chenoweth and Murday, 2003; Moneypenny and Aldrich, 2016). The reasons why online and F2F learners achieve comparable results for speaking skills might be that synchronous video-based computermediated communication (CMC) is very similar to F2F communication (Yanguas, 2010) and that online learners' weekly conversations with the instructor may surpass the individual practice of F2F learners, who often take classes in groups of 25 to 30 students (Blake et al., 2008). 


\section{Methodology}

\section{Research context}

The central aim of this paper is to compareonline and F2F adult learners' achievements in formal Dutch L2 courses. The level of the course addressed is Waystage (or A2 in the Common European Framework of References of Languages, CEFR). The provider is a center for adult education in Flanders, Belgium. The level requires 120 hours of study time. (The previous level, A1 or Breakthrough, also comprised 120 hours of study). Students who pass, receive a certificate of Dutch L2 level A2 (Waystage). The online course is 95\% online, which is legally the maximum allowed share of online learning in Flanders. The learners take all the lessons (including the introductory session) online and only take the final assessment at school.

\section{Participants}

The participants in the current study are adult immigrants who have finished the Breakthrough (A1-level) course in Dutch L2 learning and take the Waystage (A2-level) Dutch L2 course in the next semester. Their performance level is the same at the start of the course.Twenty students take the fully F2F course, nineteen the online course. In the online group, eight learners are male and eleven are female; in the F2F group, there are twelve male and eight female learners. In the F2F groups, there are more learners with a lower prior educational level than in the online group. ${ }^{8}$ Eighteen out of the twentylearners who registered for the online group, had also taken the previous Dutch L2 course online. All thelearners who registered for the F2F group, had taken the previous level F2F.

\section{Teacher}

The teacher is the same in both the online and F2F groups. He is experienced in online and F2F teaching of Dutch L2, also in the A2 level courses.

\section{Course and assessment}

Both courses, F2F and online, are based on the Common European Framework of References (CEFR) and includeall the learning outcomes of level A2 (or Waystage). The contexts of the lessons cover the four domains of language use (personal, public, occupational and educational). The learning materials have a communicative approach and

\footnotetext{
8In another comparative study of Dutch L2 learning, which is currently undergoing review, findings indicated that the prior educational level did not have an effect on the learning results.
} 
involve the acquisition of the four skills (reading, writing, listening and speaking).The duration of the course is one semester for F2F as well as online students. The final exam is held at school. Online and F2F students take the same written and oral exams.

The content of the online course is similar to the content of the books used in the F2F groups, including the four broad domains of language use (professional, educational, personal and public) as described in the CEFR. The content relates to the seven student roles (manager of housing and family administration, consumer, learner/student, participant in leisure activities, educator/coach (as a parent), worker, jobseeker, entrepreneur) as described in the Training Profiles Dutch L2 (Opleidingsprofielen NT2).

Computer-mediated Communication (CMC) in the online groupincludes synchronous(weekly individual 15-minute skype sessions with the teacher) as well as asynchronous interaction (oral exercises in Flipgrid; writing exercises in Google Drive; learning objects; e-mail for interacting with the teacher).

For both the online and F2F groups, the continuous assessment part represents $60 \%$ of the total grade, and the final exam, which is held at school, makes up $40 \%$ of the total grade.The continuous assessment as well as the final exam include the four skills (reading, writing, listening and speaking). Though some assignments for the continuous assessment are slightly different for online and F2F learners, the content, learning outcomes, level of difficulty, question types and the relative amount of the variousquestion types are very similar. The final exam is exactly the same for both groups. The passing marks are fifty percent for the final exam, and fifty percent for the continuous assessment. This is the same in both the online and F2F groups.

\section{Data}

Prior to commencing this study, informed consent was obtained from the A2-level course participants to use the results for scientific research. Then, the students' continuous assessment scores and the final exam scores of the four skills (reading, writing, listening and speaking) were collected for analysis.

\section{Statistical analysis}

SPSS version 24is employed to performLevene's tests to assess the equality of variances for the variables reading, listening, writing, speaking, total exam score, continuous 
assessment and final total score for the online and F2F groups. Subsequently, independent samples t-tests were performed to compare the online and F2F students' performance.

\section{Results}

Dutch L2 adult learner achievement in A2 level online and F2F learning modes Table 1. Scores of online and F2F Dutch L2 learners in A2-level course.

\begin{tabular}{|c|c|c|c|c|}
\hline & $\begin{array}{l}\text { Mean } \\
\text { SD }\end{array}$ & $\begin{array}{l}\text { Mean } \\
\%\end{array}$ & $\mathrm{t}$ & Sig. \\
\hline Exam reading /15 & $\begin{array}{l}12.16 \\
(1.77)\end{array}$ & $\begin{array}{l}10.95 \\
(2.18)\end{array}$ & -1.89 & .066 \\
\hline Exam listening /15 & $\begin{array}{l}11.18 \\
(2.08)\end{array}$ & $\begin{array}{l}11.68 \\
(1.92)\end{array}$ & .77 & .448 \\
\hline Exam writing / 20 & $\begin{array}{l}12.68 \\
(4.74)\end{array}$ & $\begin{array}{l}11.73 \\
(5.74)\end{array}$ & -.57 & .574 \\
\hline Exam speaking /30 & $\begin{array}{l}21.21 \\
(5.22)\end{array}$ & $\begin{array}{l}19.65 \\
(7.24)\end{array}$ & -.77 & .447 \\
\hline Exam total /80 & $\begin{array}{l}57.24 \\
(12.04)\end{array}$ & $\begin{array}{l}54.00 \\
(14.03)\end{array}$ & -.77 & .445 \\
\hline $\begin{array}{l}\text { Continuous assessment } \\
/ 120\end{array}$ & $\begin{array}{l}95.53 \\
(15.52)\end{array}$ & $\begin{array}{l}80.93 \\
(20.70)\end{array}$ & -2.48 & $.018^{*}$ \\
\hline Total $/ 200$ & $\begin{array}{l}152.76 \\
(22.71)\end{array}$ & $\begin{array}{l}134.93 \\
(33.55)\end{array}$ & -1.93 & .061 \\
\hline
\end{tabular}

Levene's test was used to measure whether or not equal variances in the online and F2F groups can be assumed. The online and F2F students' ( $n=39)$ scores were compared by means of independent samples t-tests.

First, the test was conducted to compare the reading scores for the online and F2F students, with the maximum score beingfifteen. As can be seen from table 1, the test results indicated that online learners $(\mathrm{M}=12.16$; $\mathrm{SD}=1.77)$ performed better in reading than $\mathrm{F} 2 \mathrm{~F}$ students $(M=10.95 ; S D=2.18)$, though not significantly $(t(37)=-1.89 ; p=.066)$. 
For listening, the maximum score was also fifteen. The scores for listening between online $(M=11.18 ; S D=2.08)$ and $F 2 F$ learners $(M=11.68 ; S D=1.92)$ are not significantly different $(\mathrm{t}(37)=.77 ; \mathrm{p}=.448)$. These results suggest that $\mathrm{F} 2 \mathrm{~F}$ learners perform slightly better in listening skills than online learners.

For writing, the maximum score was twenty. There was no significant difference between the scores of the online $(M=12.68 ; S D=4.74)$ and $F 2 F(M=11.73 ; S D=5.74)$ learners; $\mathrm{t}(37)=-.57, \mathrm{p}=.574$. These results suggest that online students have slightly better writing skills than F2F learners, but the difference is statistically not significant.

For speaking, the maximum score was thirty. There was no significant difference in the scores for speaking between online $(M=21.21 ; S D=5.22)$ and $F 2 F$ learners $(M=19.65$; $\mathrm{SD}=7.24) ; \mathrm{t}(37)=-.77 ; \mathrm{p}=.447$. These results suggest that online learners perform slightly better than F2F learners in listening skills, but the difference is statistically not significant.

The score for the sum of the final exam parts (reading, listening, writing and speaking skills) was eighty. As can be seen from table 1, the test results indicated that online learners $(M=57.24 ; S D=12.04)$ performed better in the final exam than $F 2 F$ students $(M=54.00$; $\mathrm{SD}=14.03)$, though not significantly $(\mathrm{t}(37)=-.77 ; \mathrm{p}=.445)$. These results suggest that online and F2F learners overall have comparable exam grades.

For the continuous assessment, the maximum score was one hundred and twenty. There was a significant difference in the scores for continuous assessment between online $(M=95.53 ; S D=15.52)$ and F2F learners $(M=80.93 ; S D=20.70) ; t(37)=-2.48 ; p=.018$. These results suggest that online learners perform statistically significantly better than F2F learners in continuous assessment.

The overall maximum score (the sum of the exam score and the continuous assessment score) was two hundred. There was no significant difference in the scores between online $(\mathrm{M}=152.76 ; \mathrm{SD}=22.71)$ and $\mathrm{F} 2 \mathrm{~F}$ students $(\mathrm{M}=134.93 ; \mathrm{SD}=33.55) ; \mathrm{t}(37)=-1.93 ; \mathrm{p}=.061$. These results suggest that online and F2F learners have comparable final grades.

\section{Discussion and conclusions}

The aim of the present study was to determine if fully online L2 learning of Dutch can be as effective as F2F learning.In accordance with the present results, previous 
comparative studies evaluating learner performance in online and F2F language courses showed marginal differences between both groups, with the online learners performing at least as good as the F2F learners. It has previously been suggested that oral skills are harder to manage in online learning formats(Sánchez-Serrano, 2008). This does not appear to have an effect on the learning results. Comparison of the findings with those of other studies (Blake, R., Wilson, N., Pardo Ballester, C. and Cetto, 2008; Chenoweth, Jones and Tucker, 2006; Chenoweth and Murday, 2003; Moneypenny and Aldrich, 2016) confirms that online learners can reach at least the same oral proficiency level as their F2F counterparts. A possible explanation could be that online learners get more personal attention from the teacher than F2F learners studying Dutch in large groups, as was already suggested by Blake (2013).

Returning to the question posed at the beginning of this study, it is now possible to state that online Dutch L2 learningand teaching environments and processesare effective and could thus provide an alternative for F2F Dutch L2 learning, for those students who are in need of a different learning format. These findings may open up new horizons for teaching LCTLs online: it might be a solution to reach special target groups, to create more flexible learning solutions for L2 learners combining different demands, or to reach people who want to study a LCTL from abroad.

\section{Limitations of the current study}

Due to the number of participants, this study is exploratory in nature. Despite these promising results, questions remain. In the field of L2 learning and teaching, there is abundant room for further progress in exploring the instructional design of online L2 courses, especially for LCTLs; in developing a quality framework for online language (and L2) courses, and in determining which kind of teacher training is necessary to prepare teachers for teaching online. Regarding learning results, more comparative studies are needed for different LCTLs. 


\section{Affordances of the current study}

The importance and originality of this study is that it compares the performance of fully online and fully F2F students of a less commonly taught second language, Dutch, for which no previous research is available. Moreover, most key variables are controlled: the course level, learning objectives, final exam and the teacher.This study has demonstrated, for the first time, that online Dutch L2 learning can be an efficient alternative for the traditional, F2F courses, while providing more flexibility for the learner.

\section{References}

Blake, R. J. (2013). Brave new digital classroom: Technology and foreign language learning. Washington, D.C.: Georgetown University Press.

Blake, R., \& Delforge, A. (2007). Online Language Learning: The Case of Spanish Without Walls. In B. Lafford \& R. Salaberry, The art of teaching Spanish: Second language acquisition from research to praxis (pp. 127-147). Georgetown: Georgetown University Press.

Blake, R., Wilson, N., Pardo Ballester, C. and Cetto, M. (2008). Measuring oral proficiency in in distance, face-to-face, and blended classrooms. Language Learning and Technology 12 (3), 114-127.

Chenoweth, N. A., Jones, C. M. and Tucker, G. R. (2006). Language online: Principles of design and methods of assessment. In Changing Language education through CALL, edited by R. P. Donaldson and M. A. Haggstrom. Abingdon: Routledge.

Chenoweth, N. A. and Murday, K. (2003). Measuring student learning in an online French course. CALICO Journal 20 (2), 284-314.

Coleman, J. A. and Furnborough, C. (2010). Learner characteristics and learning outcomes on a distance Spanish course for beginners. System 38, 14-29.

Moneypenny, D. B. \& Aldrich, R. S. (2016). Online and Face-to-Face Language Learning: A Comparative Analysis of Oral Proficiency in Introductory Spanish. The Journal of Educators Online 13 (2), 105-133.

Sánchez-Serrano, L. (2008). Initiation by fire: Training teachers for distance learning. In S. Goertler \& P. Winke, Opening doors through distance language education: Principles, 
perspectives, and practices. CALICO Monograph Series, Volume 7, 153-174. San Marcos, TX: CALICO.

Sun, S. Y. H. (2014). Learner perspectives on fully online language learning. Distance Education 35 (1), 18-42.

White, C. J. (2016). Distance Language Teaching with Technology. In C. Chapelle, \& S. Sauro (Eds.) The Handbook of Technology and Second Language Teaching and Learning. (pp. 134 - 148). John Wiley \& Sons.

Yanguas, I. (2010). Oral computer-mediated interaction between L2 learners: It's about time. Language Learning \& Technology 14, 72-79. 